\title{
A Community, a Remedy against Social Fragmentation in Roots, the Saga of an American Family
}

\author{
May Matta ${ }^{1}$ \\ ${ }^{1}$ Faculty of Letters and Human Sciences, Lebanese University, Lebanon \\ Correspondence: Assoc. Prof. May Matta, Faculty of Letters and Human Sciences, Lebanese University, \\ Lebanon. E-mail: mayochedid@hotmail.com
}

Received: December 2, 2016 Accepted: December 27, 2016 Online Published: January 20, 2017

doi:10.5539/ells.v7n1p1 URL: http://dx.doi.org/10.5539/ells.v7n1p1

\begin{abstract}
Alex Haley embarks on a journey to discover his roots, based on the stories he had been told by his grandmother. His visit to Gambia and his conversations with griots yield the amazing book, Roots. The book explores various themes including religion, race, manhood, and community. Of these themes, community stands out most. Throughout the book, Alex Haley mentions the different ways in which the community remains together despite the challenges. During all the phases of enslavement, the role of the community in the lives of the Africans is evident. Therefore, this research provides evidence that community is the remedy against social fragmentation in Roots. Moreover, the research informs the reader about the meaning of community to one of the main characters, Kunta. It also touches on the ways in which African slaves managed to retain their identity in a foreign land, despite the hindrances to community unity.
\end{abstract}

Keywords: Roots, community, social fragmentation, African traditions, slavery, Alex Haley

\section{Introduction}

Roots is the work of the accomplished American author, Alexander "Alex" Haley. Before this life-changing publication, Haley worked with media houses such as Reader's Digest and Coast Guard (Gale, 2016). His first book was The Autobiography of Malcolm X, which sold millions of copies and attained a position among the most influential nonfiction books during its time. Haley sees the need for black people to know and understand their history: from Africa, to slave trade and slavery in a foreign land, until today (Shirley \& Wagner, 2009). Therefore, he sets out to discover his roots from Juffure, a Gambian village. Haley learns his tale from oral historians trained to tell stories about the community. He is believed to be in the family line of Kunta Knite, who had been abducted when collecting wood in Juffure. In Roots, Haley explores the story of Kunta Knite and the following six generations.

This book has had a great impact on the American population. It has helped white Americans gain a better understanding of History and made them more sensitive to slavery (Global Net Production, 2007). To the African Americans, the book gives them the chance to momentarily ignore the painful history of slavery and take pride in their heritage. Some of the themes that emerge from Roots are race, African heritage, manhood, freedom, oral tradition, assimilation and separatism (Gale, 2016). Regarding African heritage, the author examines some of the traditions and practices of the African people, as well as their language .The Juffure community strong heritage makes it difficult for Kunta Knite to adjust to the new environment in America. The issue of race arises because Kunta has to deal with the whites and the mixed-race people he dislikes. Throughout the book, the value of community and family is prominent. This research seeks to show that community is a remedy against social fragmentation in Roots.

\section{Discussion and Analysis}

\subsection{The Community in Juffure}

A community comprises people who live in the same geographical location and have similar characteristics. In Juffure, a community means more than a geographical location as people share a common view of the world, which includes religion, traditions, and cultural practices. From the beginning of the story, it is evident that families in this community share meals together, especially porridge, their traditional breakfast prepared by using earthen pots. The women use three stones to build a fireplace on which they prepare their meals. The author also 
presents the people's religious beliefs and practices early in the book. The terms "Allahu Akbar! Ashadu lailahailala!" indicate that the people of Juffure are Muslims. The men have to make five prayers every day, under the leadership of an alimamo (Haley, 1974, p. 3).

The people in Juffure believe in the existence of evil spirits. For example, the people keep charms at the head of their beds to drive away evil spirits (p. 9). An elderly woman in the village tells children about a time when there is not enough rain (p. 15). The burning sun is sometimes out just two days after the rain stops. The villagers resort to deep prayers, sacrifices, and the ancestral rain dance, beseeching Allah to bring the rains back. Their efforts are in vain as everything around them begins to wither and die: water holes become dry and people and animals fall ill. To the villagers, their homes have been invaded by evil spirits. Allah seems far out of reach even after they have sacrificed the loss of their cattle. Many people die while others surrender as slaves just to nurse the hunger pangs. It is not until Kunta prays and fasts for several days that Allah hears the prayers and heavy rains pour down on Juffure. This implies that the people of Juffure are united, not only in worshipping Allah but also in prayer to free their land of evil spirits and any other negative incidents.

Moreover, the author presents the culture of the people of Juffure as regards familial hierarchy and gender roles. The men are considered the heads of the families and are accorded much respect by the women. When they come back home from the early morning prayers, they are served porridge before anyone else. The women only partake of the breakfast once they feed the children. However, both the women and men are expected to work.

The main economic practice in Juffure is farming. Hence, the men go out immediately after breakfast to till the land. They plant crops such as cotton and ground nuts. According to Haley (1974), the women have a bigger burden because they help the men and still tend vegetable gardens around their homes where they plant cassava, onions, and gourds, among other crops. Besides, harvesting is customarily done by the women. Neither the men nor the boys help. The women with their daughters harvest, transport the harvest to the village, and keep the harvest in the storehouse (p. 42). This is contrary to the common view that women are only responsible for house chores: cooking and taking care of children (Strong \& Cohen, 2014). In Juffure, all people play a role in providing the necessities for their families, regardless of their gender.

Every year, the people in Juffure celebrate the end of the harvesting period with a seven-day harvest festival that brings together crowds. Such ceremonies are common in the traditional African societies. A variety of activities usually take place. For example, the women and older girls dry medicinal roots and spices in preparation for the festivals, while the musicians are ready with drums, koras, and other melodious instruments. The villagers clean their huts and slaughter goats that will be roasted. The harvest festival is only one of the many festivals that are held across the African continent. According to Ejizu (2016), some of the festivals are linked to the people's economic practices and their religious affiliations, while others are considered as key events in people's lives. The importance of these festivals is seen in the resources that people usually invest to make them successful.

In traditional African communities, a person's name was a significant aspect of cultural identity. African names were associated with meaning as defined by the community. Moreover, names were used to reflect an individual's spirituality, life philosophy, or world events that occurred during a person's birth (Clasbery, 2012). In Juffure, the men in the village are expected to pick names for their children; the names are expected to carry a history and promises. According to the Mandinkas, children inherit seven characteristics from the person they are named after (p. 4). This means that a child named after a great leader is expected to display various leadership qualities later in life. Therefore, it is necessary to make careful considerations before naming a child. In the case of Kunta, he has taken the name of his late grandfather, Kunta Knite, a noble person known as the village's holy man. He has selflessly saved the people during a famine, and the same strength and character are expected of his grandson. Moreover, when the children are eight days old, they are named in a ceremony attended by villagers and family members. It is apparent that receiving a name means full membership of the tribe. The naming exercise is accompanied by offering food and dancing. For example, Kunta's naming ceremony is highly regarded; his father, Omoro, has invited villagers and extended family members, and the women there have brought sour milk and munko cakes (p. 5). Tan-tang drums are played by Karamo Silla. Some rituals are performed before the child is named. For example, the alimamo, the spiritual leader, has to pray for the food, then for the infant. Among the things the alimamo seeks from Allah through this prayer is a long life for the infant and success later in life. He also prays that the infant may grow into a respectable person and bring honor to the family and the community in general. In addition, reciting the names of revered ancestors is another ritual performed during the naming ceremony.

Another important practice in Juffure is marriage. Just like any other community around the world, these people have their own rules and guidelines governing the marriage institution. For example, the men are expected to live 
away from their wives. In accordance with the Muslim religion, husbands are allowed to take in a second wife when the first wife is nursing a child (p. 9). In fact, the Islamic religion allows men to marry up to four wives (Muhametov \& But, 2013). As Thobejane \& Flora (2014) concur, polygamy, mainly influenced by religious affiliations, is still a common practice in Africa, especially in the Western regions.

All the cultural practices and traditions mentioned above give a general picture of the community in Juffure. It is evident that community to the people of Juffure means togetherness and intimacy. The people worship together, celebrate ceremonies together, help each other where necessary, and allow their children to interact and play together.

\subsection{What Community and Family Meant to Kunta Knite before Enslavement}

Kunta has understood the value of community since he was young. Growing up, Kunta and his friends happily play in the rains. When there is a crisis and no mood for play, the friends still stick together. In one incident, Kunta caught a plague and the other children quickly took him to his grandmother who attended to him. Their unity is further seen during the famine in Juffure. Hungry and tired, the boys would sit together and make an effort to chat cheerfully. They would herd together under the fierce heat in the fields that made some of the boys return home with bleeding feet (p. 59). Therefore, to Kunta, community means being together in both the good and bad times, and selflessly caring for those in need.

When Grandma Yaisa died, Kunta was hit by so much grief and sadness that he could not spend time with his age mates anymore. Rarely did he eat or get enough sleep. To relieve him from all the sadness, Omoro told Kunta what it really meant to be a community. He constantly tells him that all villages have three groups of people; the ones alive, the ancestors, and those yet to be born. The description helps Kunta understand that the community encompasses anyone that has or will ever be part of it. Even though Grandma Yaisa had gone, she was still part of the community. This new level of understanding becomes very influential in Kunta's life, explaining why he is keen on embracing the many things he has been taught by his father and his grandmother. Consequently, any knowledge his father and his grandmother imparted to him would also be of good to the entire community.

In addition, kafo training teaches Kunta the value of community. This form of training is tailored towards achieving different goals in the African society. For example, teaching the boys warfare tactics ensures that they could safeguard their families and the community (Black, 2012). In Juffure, the old kin tango has stringent rules and he has the authority to punish the entire kafo for a mistake done by one of the boys, therefore, the rest of the boys will neither fight back nor fight among themselves. Through such experiences, the boys understood that they had a role to play both in the small group and in the entire community. They would one day be responsible for the welfare of the whole Mandinka community.

Kunta's perception of family and the community is further evident when he comes back home from manhood training (p. 158). He knows everything about his village, from the people to the goats and dogs. He meets and talks to most of the villagers on a daily basis, yet he always feels very lonely. Kunta realizes that his loneliness is emanated from the growing rift among his family members. His parents are too busy to spend time with him while his siblings have formed a bond that had never existed before. He is left alone, forced to take solitary walks around the village. This teaches Kunta that the family is the foundation of the community. Interacting with other villagers doesn't mean much if the immediate family members are no longer close. More precisely, the community loses its meaning when families grow apart.

Kunta's love for the people of Juffure is seen when there is famine in the land. People and animals die, while some of the villagers are taken as slaves in order to get food. Kunta is concerned about their plight and chooses to pray for four consecutive days with only a few drops of water to sustain him (p. 15). Amazingly, the rains pour on the fifth day. He cares for the villagers as much as he cares about his family. This implies that, to Kunta, community means love, care, and concern.

\subsection{Family and Community Unity in Juffure}

There are a variety of factors that make it possible for families and the entire Juffure community to remain united, one of which is religion. Most of the villagers share the beliefs and practices of the Islamic faith. The doctrine of this religion provides guidance on the villagers' daily lives promoting peace and order. For example, according to Phillips (2015), the Koran encourages Muslims to remember Allah in everything they do as a means of attaining inner peace. It teaches them to love, be compassionate, and share with those in need (Ferguson, 2012). Subscribing to this religion, therefore, forms the basis of peace and unity among the people of Juffure. The men have to meet five times a day for prayer, further boosting unity in the village. Kunta himself is well-versed with 
the Holy Book and proves his knowledge before the villagers when he graduates from the Arafang School (p. 113).

Moreover, the people of Juffure are united by the festivals and ceremonies they hold every year. As earlier mentioned, the villagers would gather together to name children, eat together, dance, celebrate, and make lively conversations. Out of the activities conducted during the festival, music plays a significant role in promoting peace and unity.

Juffure has musicians who entertain crowds with a variety of instruments including balafons and koras (p. 44). Many researchers concur that music is an important tool in promoting cultural cohesion. According to Suttie (2015), sharing similar music gives people a sense of belonging. Take for example the way children love the songs that are passed down from one generation to another. They sing and dance joyfully, and even in adulthood remembering the songs puts a smile on their faces. Indeed, as noted by Onuekwe (2015), music affects people's thoughts and actions; hence, it can be used to promote healthy behaviors. A musician can promote peace by singing about the dangers of violence, hate, and other vices. Suttie (2015) too observes that families who listen to music together display higher levels of cohesion. In the same way, the community benefits from dancing and listening to music. Through music, the people can encourage each other, laugh, and forget about their difficult situations.

Moreover, unity in Juffure is achieved through the help of community leaders and family heads. Fathers probably mold their children to become noble people in the future, valuing the other villagers and working towards the good of the community (Takacs \& Cline, 2015). Most importantly, a council of elders is encharged of key decision-making in Juffure. The elders are role models to the young and a source of comfort, encouragement, and guidance for the entire community. In the traditional African community, such councils comprise elderly men who are considered wise enough to give offer counsel (Porto, 2016). They offer a variety of services among them resolving conflict resolution and maintaining peace. Consequently, they have a great influence on the people as they help them overcome the difficulties they face. Unfortunately, the people of Juffure have to endure famine, pandemics, and other challenging situations. Despite all the difficulties, they remain united and console themselves through music, dance, festivals, and religious practices.

\subsection{Oral Tradition and What It Meant to the Community}

Oral tradition is one of the most important themes in Haley's book. Kizza (2010) views oral tradition as encyclopedia of traditions, histories, and cultural experiences in different communities. Haley gets to learn about his story through tales told from one generation to the next. From an early age, his grandmother told him tales about how Africans were captured by the whites and subjected to slavery in a foreign land. She also narrated about Africans' futile attempts to escape that led to the growth of today's African American community. When curiosity leads Haley to Gambia, oral tradition makes it possible for him to obtain the information he is searching for.

Fortunately, Gambia has griots (oral historians) who narrate stories about the past of the people in villages such as Juffure. The griots are well-versed with the community's history; therefore, they have a lot of information about the families living within their areas of operation, as well as about key events and occurrences such as wars and famine. Therefore, anyone interested in such information seeks these people. Griots preserve the history, culture, and traditions of a particular community through music or storytelling (Alexander \& Rucker, 2010). Griots used to receive gifts for their work but later on in time, they were obliged to engage in other activities to earn their living. They now offer their services during weddings, naming, and ceremonies.

In traditional African communities, stories were used as a means of passing knowledge regarding the communities to the younger generations. Stories were used to chart the communities' social progress and enlighten the younger generation on the experiences of the community ranging from wars, its leaders, droughts and famines, and migration among others (Ce \& Smith, 2014). It is believed that oral tradition enables Kunta, Haley's ancestor, to learn much about the history of his community. For example, through the stories told by his father and his grandmother, he learns about slavery in the other African communities. There are different explanations as to why some villagers are slaves. For some of them, their mothers were slaves in the past; some had surrendered to slavery to avoid starvation, while others had been captured by their enemies (p. 70). The community's forefathers had set guidelines on how to treat the slaves. Masters are expected to feed, clothe, house the slaves, and let them marry. Omoro goes on to tell his son about Sundiata, an ancient slave. He, in the same way, has been told about this great man by his grandmothers and griots. Furthermore, Kunta learns about white slave raiders from his grandmother. She has told him how villagers are abducted, bound neck-to-neck, and forced to walk across the country to a slave trading center. Those that aren't able to endure hunger and 
exhaustion are left to be devoured by the wild animals (p. 73).

Stories are told also during manhood training, focusing on different aspects of the Mandinka's history and cultural practices. In one such session, the boys have been informed about war. The king tango informs them that the members of the community only fight if they encounter warlike people and he also teaches them some of Mandinka's popular battle strategies (p. 134). However, none of the warriors are engaged in war that may harm griots or blacksmiths. The Mandinkas believe that hurting this revered group of people stirs Allah's anger and leads to devastating outcomes in the community. Furthermore, the boys have learned about their community's greatest wars in history. These and many more stories in the book show how important oral tradition is to the people of Juffure. Through songs and stories, the people understand the community's deepest secrets, the existing cultural practices and traditions. Through oral tradition, Kunta has gained his identity within the community, which explains why he has difficulties adjusting to the norms and practices of the new land, America.

\subsection{The Community after Kunta Enslavement}

\subsubsection{Maintaining Identity}

The people taken into slavery in America have made an effort to retain their African identity. For example, Kunta includes a touch of his African heritage in what he practices, does, and performs. For instance, he made a Mandinka doll as a gift for Kizzy on her second birthday. He made sure that the doll attained the luster of the ebony carvings that were made in Gambia. This way, he is able to pass down some aspects of the Mandinka culture to the following generation. Kunta also taught his daughter some Mandinka words since an early age (p. 485). He was very impressed by how at first Kizzy learned the new words. To Kunta, this was an indication that there was still some hope left for the slaves. He also narrated his enslavement story to the little girl. Ayers (2009) points out that the Africans influence the speech patterns that are adopted by the whites. Thus, some African words such as cola and goober (peanut) became American vocabulary.

In addition, the people maintain their African heritage by preparing African food. When Kunta arrives home after a tiresome day, he is welcomed with his favorite African stew. Different African communities have different meals which they prepare on a daily basis or on special occasions. Continuing to indulge in these dishes in a foreign land restores the people's sense of identity and belonging. For example, through the Africans, Americans learn about frying food and using spices (Green, 2006).

The Africans' dedication to retaining their identity is further seen when Kizzy has to name her son. Massa Lea suggests that they call him George and Kizzy only remains silent because she fears igniting his anger (p. 582). However, she prefers to call him Knite or Kunta. Naming is a very important exercise in the African culture, so she wonders how she could name the boy George without making Kunta angry too. She vows that her son will remain a grandson of the African regardless of the name that Massa Lea chooses for him. In her view, the baby's skin complexion and his origin do not matter. Just like Kunta, she promises to teach her son about their African heritage. As George grows older, he becomes very inquisitive, especially because he is not as black as his mother. $\mathrm{He}$ asks about his father and Kizzy is forced to tell him about his grandfather Kunta and how he has been captured in Africa and made a slave in the new land. Keeping the sense of belonging alive, she teaches him words like 'Ko' and "Kamby Bolongo" that she has learned from her father. This story is passed down to Kunta's sixth generation.

Moreover, those taken to slavery have sought to maintain their identity by planning revolts against their masters. One of the most successful revolts during the transatlantic slave trade era was the Saint Domingue Revolt (Hinks, 2006). Sometimes slaves' quest for freedom could turn deadly leading to many deaths and property destruction. In one such incident, Massa Lea is distraught when he learns that one of the religious leaders, Nat Turner, organizes a revolt (p. 688). The Blacks attack the homes of the white slave masters, which results in the death of many people, women and children. Massa Lea and the other white men retaliate by forcing the blacks to remove their luggage out of their cabins in order to investigate and confiscate any hidden weapons or suspicious objects.

\subsubsection{Building New Relationships}

Kunta has been captured together with other villagers by the toubob, the white people. They have been bated and shoved together within hard plank shelves. They have screamed and prayed, pleading with Allah to set them free (p. 208). Drastically, Kunta has realized that he won't ever set foot on his homeland again. The beating continues as they journey on to an unknown land, but the people try their best not to scream. The author states, “...just listening to the force of the blows was almost paralyzing to Kunta," (p. 212). This reflects the intensity of the pain and agony that the captives have to endure. There is no hope left for the Africans until one reassuring voice 
of an elder is heard. "Share his pain! We must be in this place as one village," (p. 213). Suddenly, Kunta and the rest of the captives have realized that although they have lost their home, they still have each other. This is the first step to building new relationships in slavery. It is well-known that the groups of captives are comprised of people with different backgrounds, including the Mandinkas, Serer, Wolof, and other communities. Kunta finds a new community to share his pain, fears, and worries. He no longer wants to die but to live and fight for his people. Beginning to communicate and developing a new sense of brotherhood, the captives aren't concerned if they are from different villages or belong to different tribes. In fact, sharing stories about their villages allows them to shift their focus from the stink and filth in the decks they lie in. Therefore, one can rightfully conclude that the blacks begin to build relationships by sharing each other's pain.

As earlier mentioned, marriage is a very important practice in the traditional African community. Marriages are considered as the foundation of every community. Marriage partners are not only a source of companionship, but they are a means to procreate and continue the family lineage. This explains why some men are forced to look for other wives if the first turns out to be barren. In the foreign land, Kunta and the other slaves build new relationships through marriage. Marriage enables them to create a new generation of people that gives them hope for a better future. The Africans marry among each other but there are cases of sexual relationships between the slaves and their masters (Marjoribanks, 2007).

One woman, Bell, stands out among the many women Kunta has met in his travels. This prompts him to list down the pros and cons of dating this woman. Bell comes across as caring and considerate; Kunta is put off by her tendency to smoke tobacco and her dance style. He also doesn't like her critical nature especially in the company of other women. They begin to form a bond when Bell invites him for dinner. Eventually, Kunta gets to experience his first ever romantic relationship, and they get married a week before Christmas. More relationships are built within the year. Kunta's grandson, George also finds himself a wife, Matilda, who is a very religious girl whom George buys from her master. Soon they form a family and bear a son, Tom, who ends up marrying Irene. This family tree continues until Alex Haley is born. Building families lightens the burdens the Africans carry while in slavery. Their families give them a reason to live and bring joy amidst their struggles in the new land. Solitude, on the other hand, makes it harder for them to survive in the foreign land.

Adjusting to the new environment means slaves will have to adopt some of America's norms and practices. For example, in Juffure, most of the villagers are Muslims, but in America some of them adopt Christianity (Neusner, 2009). The author mentions Christianity many times within the book, and it is clear that, just like the Islamic religion, this religion influences people's actions. As a result, the Africans begin to celebrate Christian ceremonies. The people's practice of the new religion is also seen during the gardener's burial. Prayers are held by the graveside and Kunta is surprised to hear people call the gardener 'Josephus' an indication that he had been a Christian (p. 479). Kunta is left to wonder what the gardener's African name is. When Massa Lea suggests that Kizzy's boy be named George, Kizzy complies and mentions that she will note it down in the Bible. This indicates that in place of the Koran some of the slaves relied on the Bible.

Work is another way which enables the slaves to maintain their sanity during enslavement. Aside from the work they are made to do in the fields, people like Kunta manage to take up better jobs. Kunta becomes a driver, while others hold different positions under the jurisdiction of their owners. On the other hand, his grandson George is involved in cockfighting tournaments. Although they can't go back to their homeland, such activities bring them joy.

\subsection{Hindrances to Community Unity}

The discussion above shows the many ways in which the African community remains united despite the many struggles. However, it isn't always easy to keep the people together. For instance, the author mentions black traitors who help the slave lords with their operations. When Kunta and other villagers are captured, chained together, and thoroughly beaten, they wish that they could kill the slave masters together with their traitor black helpers (p. 210). This indicates that not all villagers can be trusted to uphold the interests of their own people. Unfortunately, some of the traitors also suffer at the hands of their masters. In addition, natural disasters like famine and floods make it hard for the Africans to remain united and retain their identity. Some of them are forced to surrender to slavery in order to get food and shelter. Becoming a slave means losing freedom and failing to stick to the community agenda in certain circumstances.

Another hindrance which being a slave likely poses to community unity has to do with the language barrier. Not only are the slaves from different tribes, but they also can't speak English well (Jones, 2013). The author repeatedly provides the exact conversations of the African characters in the story and translates some expressions but with limitations. The other hindrance to community unity is fear. The Africans don't want to anger the whites 
for fear of the consequences. For example, Kizzy fails to honor the African way of naming for fear of making Massa Lea angry. One other incident is when Bell reminds Kunta that African things bring no good (p. 488). This happens when Massa Waller discovers the rocks that Kunta stores in a guard to monitor his age. To Massa Waller these rocks are African voodoo, yet in real sense they are harmless. The Africans also have to deal with racial discrimination. Such factors make it difficult for them to retain their identity during slavery.

\subsection{The Community through the Eyes of Alex Haley}

Choosing to investigate his family history in itself reflects what family and community mean to Haley, the author. Although Haley has been told stories about his ancestors and how they were captured from Africa and transported to America, he doesn't stop at that but chooses to go to Gambia to know more about his roots. It doesn't matter that his people have been in America for years, he still feels a sense of belonging to the African community. Through the book, he helps African-Americans see their rich African heritage, understand their past, and appreciate who they are in the present. In the book, Haley finds ways of keeping the community alive. For example, he provides the details of the different happenings in Juffure: ceremonies, festivals, and kafo training. He explains how the villagers would come together to prepare for festivals and other common events. He even gives details on how children would grow together, play and work together, and undergo training together. Providing such details enables the reader to create a mental picture of the community in Juffure early on in the book. After a few pages, the readers are able to see the unity elicited by the community, in both bad and good times. This unity enables the members of the community to overcome the many challenges that they face. In America, the author continues to highlight the importance of community, showing how Kunta and the rest of the slaves adjust to the new environment. Even though they are hesitant at first, they eventually give in to some of the regularities in the new land. The author shows how these people fight together to retain their identity, despite the many hindrances. Haley continues to focus on different aspects of community life till the end of the book. All through, the reader is reminded of how the community members have to stick together to handle the issues they face.

\section{Conclusion}

Not only does this research determine how the community helps to prevent social fragmentation in Haley's Roots, but it also reveals a lot of information about the community, both in Juffure and in America. For example, the research identifies the cultural norms and practices of the people of Juffure. Firstly, we're told that African people subscribe to the Islamic religion and believe in the existence of evil spirits and, furthermore, that they depend on Allah to rescue them from famine, pandemics, and other natural disasters. Secondly, the author explains that African people would come together during the harvest festival and other celebrations. Drastically, the order in the land is disrupted by the invasion of white slave traders who take Kunta and other people into captivity. Proud of their identity, Kunta and other people fight to create their own community of black slaves, regardless of their tribe or language. For example, Kunta makes an effort to retain the African identity by telling his daughter stories about his painful past and teaching her Mandinka words.

The findings above show the true value of community in Haley's book. From a young age, children were taught to appreciate every member of the society and never to fight against each other. This made them understand that each one of them had a contribution to make to the overall wellbeing of the community. There were famines, floods, wars, and other occurrences that could have divided the people of Juffure, but they stayed together because they recognized that they needed each other. No problem could break the bond they had built. Strong men like Kunta made a lot of sacrifices for the good of their people. For example, when the village experiences famine, Kunta prayed for four consecutive days with only a few drops of water to sustain him. He endured hunger and exhaustion for the sake of the community. When Kunta and other people were captured by the slave masters, the sense of new brotherhood sustained them. Through successes and failures, the community remains united. Evidently, a community is the remedy against social fragmentation in Roots, the Saga of an American Family.

\section{Acknowledgments}

I would like to thank the Lebanese University for giving me encouragement and support. Also, I would express my thankfulness for the committee that gives me the chance to publish my research paper. I am grateful to my daughter whose guidance and constructive criticism availed insight in various aspects of the research.

\section{References}

Alexander, L. M., \& Rucker, W. C. (2010). Encyclopedia of African American history. Santa Barbara, Calif: ABC-CLIO. 
Ayers, E. (2009). American passages: A history of the United States. Boston, MA: Cengage Learning.

Black, D. (2012). Dismantling black manhood: A historical and literary analysis of the legacy of slavery. London: Routledge.

Ce, C., \& Smith, C. (2014). African rythmns: New approaches to literature. Oxford: Handel Books.

Clasberry, E. U. (2012). Culture of names in Africa: A search for cultural identity. New York, NY: Xlibris Corp.

Ejizu, I. (2016). Readings on religion and culture in Africa. Oxford, Nigeria: $\mathrm{M}$ and J Orbit Communications.

Ferguson, D. (2012). Lovescapes: Mapping the geography of love: An invitation to the love-centered life. Eugene, Oregon: Cascade Books.

Gale, C. L. (2016). A study guide for Alex Haley's “Roots”. Farmington Hills, MI: Cengage Learning.

Global Net Productions. (2007). Yokes and chains: A journey to forgiveness and freedom. Retrieved from http://www.lifelineexpedition.co.uk/mota/downloads/YokesRoots012507C.pdf

Green, C. (2006). What we dragged out of slavery with us. West Conshohocken, PA: Infinity Publishers.

Haley, A. (1974). Roots. Bronx: Ishi Press International.

Hinks, P. (2006). Encyclopedia of antislavery and abolition. Westport, Conn.: Greenwood Press.

Jones, A. J. (Ed.). (2013). Overcoming language barriers: How teachers can help dialect speakers succeed. Bloomington, IN: Authorhouse.

Kizza, I. (2010). The oral tradition of the Baganda of Uganda: A study and anthology of legends, myths, and folktales. Jefferson, NC: McFarland.

Marjoribanks, A. (2007). Travels in South and North America. Carlisle, MA: Applewood Books.

Muhametov, A., \& But, L. (2013). Love and sex. Bloomington, IN: Booktango.

Neusner, J. (2009). World religions in America: An introduction. Louisville, KY: Westminster John Knox Press.

Onuekwe, C. (2015). Entertainment- education for health behavior change. Victoria, BC, Canada: FriesenPress.

Phillips, B. (2015). The search for inner peace. UK: Peace Vision.

Porto, G. (2016). Africa's new peace and security architecture: Promoting norms, institutionalizing solutions. London: Routledge.

Shirley, D., \& Wagner, H. L. (2009). Alex Haley. New York, NY: Infobase Publishing.

Strong, B., \& Cohen, T. (2014). The marriage and family experience: intimate relationships in a changing society. Belmont, CA: Wadsworth.

Suttie, J. (2015). Four ways music strengthens social bonds. Retrieved from http://greatergood.berkeley.edu/article/item/four_ways_music_strengthens_social_bonds

Takacs, S., \& Cline, E. (2015). The ancient world, volume (pp. 1-5). London: Routledge.

Thobejane, T., \& Flora, T. (2014). An exploration of polygamous marriages: A worldview. Mediterranean Journal of Social Sciences, 5(27), 1058-1066. https://doi.org/10.5901/mjss.2014.v5n27p1058

\section{Copyrights}

Copyright for this article is retained by the author(s), with first publication rights granted to the journal.

This is an open-access article distributed under the terms and conditions of the Creative Commons Attribution license (http://creativecommons.org/licenses/by/4.0/). 